\title{
Active Open Market Operations A Review of Experience
}

\author{
Dr. D S Wijesinghe ${ }^{1}$
}

\begin{abstract}
The Central Bank of Sri Lanka introduced a system of active Open Market Operations (OMO) on 03 March 2003 in order to manage liquidity at its own discretion and thereby to achieve monetary policy targets. Under this system, monetary policy operations are conducted to achieve a path of reserve money targets, while maintaining short term interest rates stable around a level, which is consistent with the reserve money targets. This paper reviews the experience under the system during March 2003June 2005 and presents suggestions, on the basis of the review, for improving the effectiveness of monetary policy operations in achieving their objectives. The paper highlights the need for focusing on overnight interest rates, instead of reserve money, as the operating target, determining the size of daily operations under OMO entirely on the basis of their outcome on interest rates and introducing long term repurchase transactions and auctions for multiple maturities for managing liquidity on a long term basis. (JEL E44, E52)
\end{abstract}

\section{Introduction}

The Central Bank of Sri Lanka introduced on 3 March 2003, a system of active Open Market Operations (OMO) in order to manage market liquidity actively at its own discretion and thereby to achieve monetary policy targets. The Central Bank conducts monetary policy within a framework of targeting monetary aggregates. In this framework, the final objective of economic and price stability is expected to be achieved through an intermediate target on broadly defined money supply with an operational target on reserve money. Accordingly, monetary policy operations are conducted to achieve a path of

1/ The author wishes to thank Dr. A. G. Karunasena, Asst. Governor, Central Bank of Sri Lanka for his valuable comments on an earlier draft of this paper. The assistance of Mrs. K. Dassanayake, Senior Asst. Director and Mrs. K. Mayadunne, Asst. Director, Central Bank of Sri Lanka in the preparation of this paper is acknowledged with thanks. 
reserve money targets while maintaining interest rates stable around a level consistent with the path of reserve money targets.

The objectives of monetary policy operations under this system were well realized in 2003. However, in 2004, reserve money tended to remain above the targets and interest rates displayed some volatile changes. This paper reviews the experience under this system with a view to present suggestions for improving the effectiveness of the system in achieving the objectives of monetary policy operations. The paper begins with an outline of the key elements of the system in Section 1. A review of experience during March 2003 - June 2005 is presented in Section 2. Section 3, outlines the approach adopted by the Central Bank, amidst difficult economic conditions prevailed in the country, to bring the reserve money to the target path and examines contributory factors for interest rate volatility. Suggestions for further improving the system are outlined in Section 4.

\section{Key Elements of the System}

The key elements of the present system of monetary policy operations are,

(i) Interest Rate Corridor formed by the overnight repurchase (Repo) rate and the reverse repurchase (Reverse Repo) rate of the Central Bank.

(ii) Daily Auction of Repo or Reverse Repo transactions, either to absorb liquidity from the market or inject liquidity to the market.

(iii) Standing facility.

(iv) Outright Sales/Purchases of government securities to address long term (structural) liquidity imbalances.

The interest rate corridor is the instrument to achieve the reserve money target. The corridor has an implicit target on overnight interest rates (usually in the middle of the corridor) which is considered compatible with the reserve money target. If reserve money is consistently above (below) the target, it is an indication that the corridor is not compatible with the reserve money target and therefore, needs to be shifted up (down). Usually, such adjustments are introduced at regular reviews of monetary policy which are conducted normally on a monthly interval. However, if there is a concern for adjusting the corridor, in view of other macro economic considerations, interest rates are allowed to adjust within the corridor. Such within the corridor adjustments are usually temporary, pending an eventual adjustment to the corridor.

The daily auction is the instrument to maintain the comparable overnight interest rates, stable around the implicit target. Accordingly, whenever there is excess liquidity, it is absorbed through a daily auction of 
repurchase transactions. Similarly, liquidity is injected through an auction of reverse repurchase transactions when there is a liquidity shortage. The implicit target is achieved by appropriately managing market liquidity, specially by adjusting the volume of liquidity absorbed or injected through the auction.

Standing facilities are provided at the Central Bank's Repo rate and Reverse Repo rate to those who were unable to obtain their requirements at the daily auction. A sufficient margin is maintained between the Repo rate and the Reverse Repo rate in order to make them penalty rates and thereby to encourage participating institutions to obtain their requirements at the auction.

A long term or structural liquidity imbalance is indicated by the existence of a large surplus or deficit of liquidity consistently for a long period and such imbalances are removed through outright sales or purchases of government securities.

\section{Experience during March 2003 - June 2005}

\section{A. Interest Rate Corridor and Reserve Money Target}

The present system of open market operations was introduced with an interest rate corridor of 11 per cent (Reverse Repo Rate) and 9 per cent (Repo Rate). However, as actual reserve money continued to be consistently below the target the corridor was revised down in three steps to 8.5 per cent (Reverse Repo Rate) and 7.0 per cent (Repo Rate) by October 2003, and quarterly targets on reserve money were comfortably met (Chart 1). In 2004, reserve money tended to remain above the target path and the Central Bank first conducted

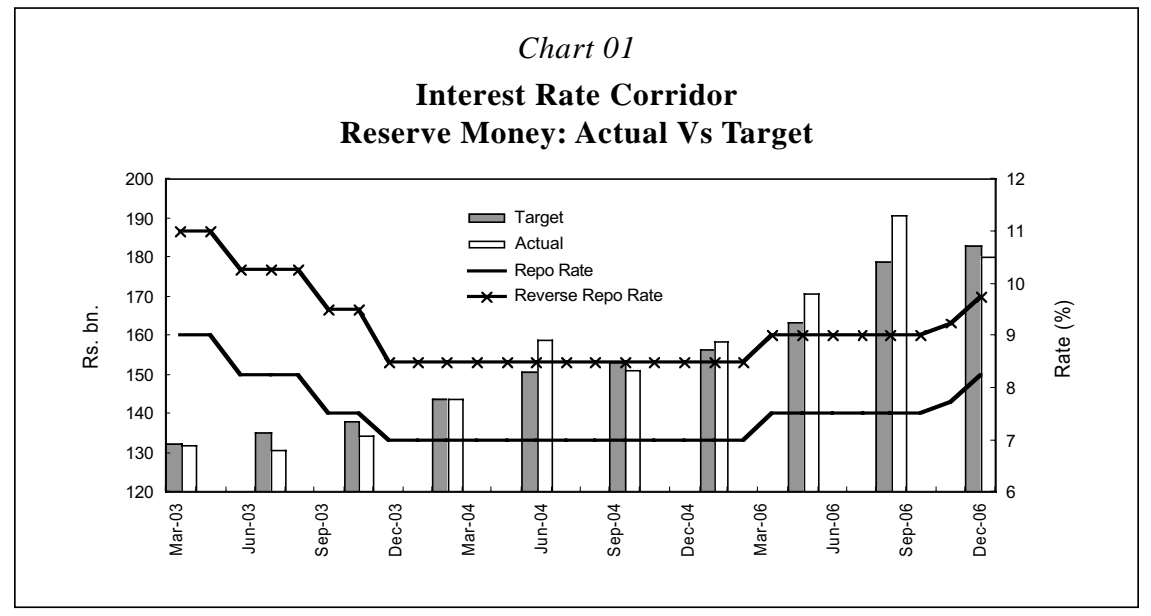


its OMO aggressively allowing an upward movement in interest rates within the corridor and subsequently shifted the corridor up by 50 bps in November 2004. The monetary policy was tightened further by shifting the corridor by 25 bps in May and 50 bps in June 2005 to 9.75 per cent (Reverse Repo Rate) and 8.25 per cent (Repo Rate). Reserve money was brought to the target path by June 2005 .

\section{B. Daily Auction and Interest Rate Stability}

During 2003, as reserve money continued to remain below the target, the Central Bank had been quite conservative in absorbing liquidity through the daily auction. Accordingly an amount equivalent to the estimated excess liquidity less the leeway between the reserve money target and the actual reserve money was offered and absorbed through the auction (Chart 2). On average, the amount offered was around 58 per cent of the estimated excess liquidity (Table I). Therefore, competitive forces pushed the weighted average yield rate at the auction down and it remained closer to the lower bound of the corridor.

During most of this period, short term interest rates remained remarkably stable (Chart 3). The stability was largely attributed to the effort made by the Central Bank to maintain liquidity in the market at a sufficiently high level (Table 2). Due to stringent limits of some banks on their lendings to other banks, normally, volatility had been observed in short term rates whenever, the liquidity surplus declines below Rs. 3 - 5 billion level. Particularly during festive seasons when the demand for liquidity is high temporarily, the Central Bank injected liquidity through purchases of Treasury bills. During March December 2003, on average, excess liquidity in the market remained around

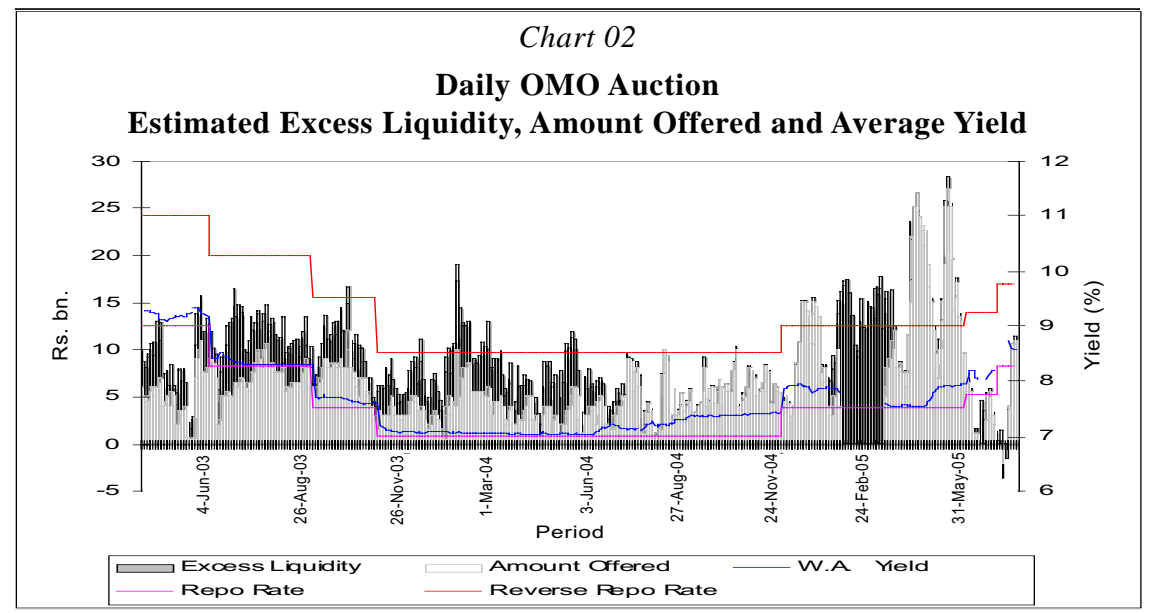


Table-01

Daily OMO Auction

Estimated Excess Liquidity, Amount Offered, Bids Received \& Accepted and Yield

\begin{tabular}{|c|c|c|c|c|c|c|c|c|c|}
\hline & & \multirow{2}{*}{$\begin{array}{l}\text { Estimated } \\
\text { Excess } \\
\text { Liqudity } \\
\text { (Rs.bn) }\end{array}$} & \multicolumn{2}{|c|}{ Amount Offered } & \multirow{2}{*}{$\begin{array}{c}\text { Bid } \\
\text { Received } \\
\text { (Rs.bn) }\end{array}$} & \multirow{2}{*}{$\begin{array}{c}\text { Bid } \\
\text { Accepted } \\
\text { (Rs.bn) }\end{array}$} & \multicolumn{3}{|c|}{ Yield (\%) } \\
\hline & & & Rs.bn & $\begin{array}{l}\text { As } \% \text { of } \\
\text { Excess } \\
\text { Liquidity }\end{array}$ & & & $\begin{array}{l}\text { Weighted } \\
\text { Average }\end{array}$ & Min. & Max. \\
\hline \multirow[t]{10}{*}{2003} & Mar & 9.23 & 5.38 & 58 & 9.93 & 5.38 & 9.17 & 9.14 & 9.19 \\
\hline & Apr & 6.56 & 3.60 & 55 & 4.70 & 3.48 & 8.70 & 8.64 & 8.74 \\
\hline & May & 6.56 & 3.60 & 55 & 4.70 & 3.48 & 8.70 & 8.64 & 8.74 \\
\hline & Jun & 12.65 & 6.86 & 54 & 11.06 & 6.58 & 8.31 & 8.29 & 8.32 \\
\hline & Jul & 11.42 & 7.41 & 65 & 9.99 & 7.31 & 8.29 & 8.28 & 8.30 \\
\hline & Aug & 9.91 & 7.23 & 73 & 8.91 & 6.59 & 7.96 & 7.93 & 7.99 \\
\hline & Sep & 11.73 & 7.98 & 68 & 10.26 & 7.89 & 7.65 & 7.62 & 7.66 \\
\hline & Oct & 6.50 & 3.86 & 59 & 5.57 & 3.84 & 7.34 & 7.31 & 7.36 \\
\hline & Nov & 6.50 & 3.45 & 53 & 5.26 & 3.44 & 7.05 & 7.04 & 7.07 \\
\hline & Dec & 7.07 & 3.02 & 43 & 4.85 & 2.96 & 7.06 & 7.04 & 7.08 \\
\hline \multirow[t]{12}{*}{2004} & Jan & 11.23 & 6.48 & 58 & 9.16 & 6.08 & 7.03 & 7.03 & 7.06 \\
\hline & $\mathrm{Feb}$ & 7.69 & 3.78 & 49 & 6.10 & 3.42 & 7.03 & 7.02 & 7.03 \\
\hline & Mar & 5.37 & 2.70 & 50 & 3.59 & 2.52 & 7.02 & 7.02 & 7.03 \\
\hline & Apr & 7.50 & 2.92 & 39 & 3.36 & 2.52 & 7.02 & 7.02 & 7.03 \\
\hline & May & 5.62 & 3.33 & 59 & 2.68 & 2.29 & 7.06 & 7.04 & 7.06 \\
\hline & Jun & 5.75 & 4.70 & 82 & 4.68 & 4.03 & 7.14 & 7.13 & 7.16 \\
\hline & Jul & 3.91 & 3.76 & 96 & 2.82 & 2.73 & 6.84 & 6.82 & 6.88 \\
\hline & Aug & 4.27 & 4.19 & 98 & 3.48 & 3.43 & 7.32 & 7.28 & 7.36 \\
\hline & Sep & 6.01 & 5.92 & 99 & 5.20 & 5.11 & 7.36 & 7.30 & 7.39 \\
\hline & Oct & 6.15 & 6.00 & 98 & 5.51 & 5.40 & 7.39 & 7.35 & 7.42 \\
\hline & Nov & 5.15 & 5.10 & 99 & 4.39 & 4.20 & 7.70 & 7.67 & 7.74 \\
\hline & Dec & 10.84 & 9.97 & 92 & 10.00 & 9.40 & 7.86 & 7.82 & 7.90 \\
\hline \multirow[t]{6}{*}{2005} & Jan & 13.86 & 7.00 & 50 & 11.73 & 6.78 & 7.81 & 7.78 & 7.85 \\
\hline & $\mathrm{Feb}$ & 14.52 & 7.80 & 54 & 12.45 & 7.36 & 7.56 & 7.54 & 7.57 \\
\hline & Mar & 15.83 & 15.21 & 96 & 14.41 & 13.80 & 7.55 & 7.54 & 7.58 \\
\hline & Apr & 17.60 & 17.17 & 98 & 16.63 & 15.99 & 7.82 & 7.77 & 7.89 \\
\hline & May & 7.72 & 7.24 & 94 & 7.02 & 6.61 & 8.01 & 7.96 & 8.05 \\
\hline & Jun & 2.64 & 2.37 & 90 & 2.24 & 2.03 & 8.39 & 8.30 & 8.53 \\
\hline
\end{tabular}

Rs. 9 billion. With the exception of a few days in April, excess liquidity in the market remained well above Rs. 3 billion on each day. Similarly, during the first four months in 2004, on average, there was excess liquidity of nearly Rs. 8 billion and except for a few days in March - April, excess liquidity remained well above Rs. 3 billion. 


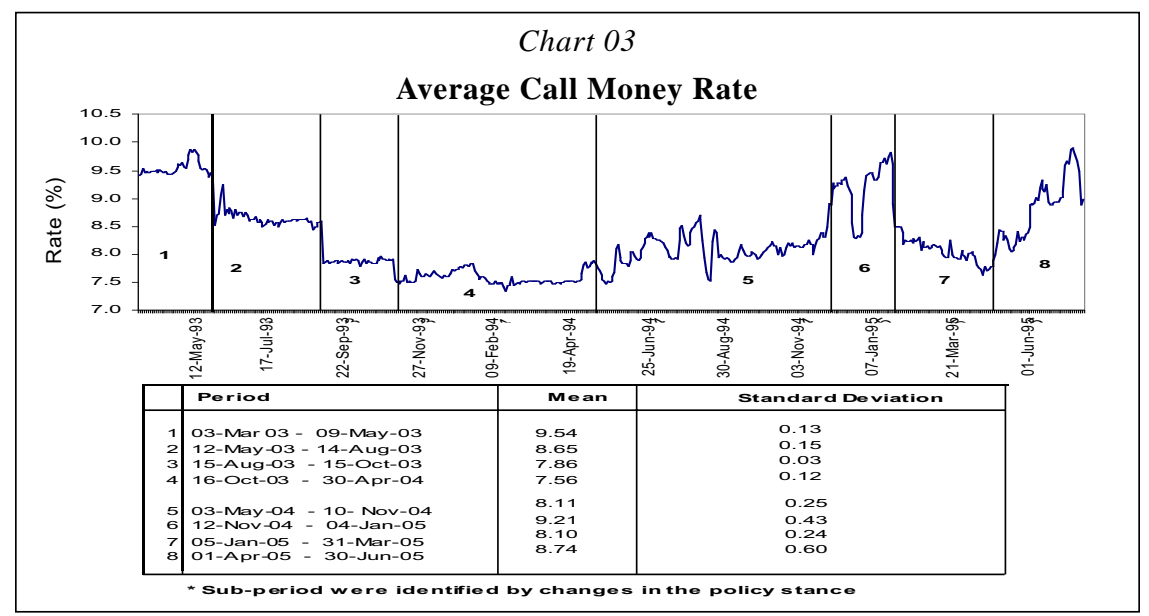

In May 2004, in view of the higher than desired rate of expansion in reserve money, it was decided to allow market rates to move up within the corridor. Accordingly, the amount offered to the market for absorption through the repurchase auction was gradually increased to almost the entire estimated liquidity surplus. This practice resulted in gradually moving up the average yield rate at the auction from 7.02 per cent at end April 2004 to 7.40 per cent by 14 October 2004, a margin of 40 bps compared to the Repo rate of the Central Bank. With the upward adjustment of the interest rate corridor by 50 bps on 12 November 2004, the auction rate moved up to 7.86 per cent and remained around 7.88 per cent on average during 12 November - 24 December 2004. During the second half of 2004, particularly in July - August, excess liquidity declined sharply, largely due to transactions of the Central Bank in foreign exchange and the Central Bank was rather cautious in injecting liquidity to maintain excess liquidity in view of the higher than desired rate of monetary expansion. Therefore, together with the upward movement in the auction rate, some volatility in interest rates was observed during this period.

Following the Tsunami disaster on 26 December 2004, the absorption of liquidity through the auction was first substantially reduced and then during 5 January - 18 February 2005, temporary suspended to ensure smooth functioning of the money market and the payment and settlement system. In addition, the Central Bank was quite liberal in providing liquidity through purchases of Treasury bills, in view of the needs for relief and rehabilitation work in areas affected by Tsunami. During January - February 2005, excess liquidity remained around Rs. 14 billion on average with a maximum of Rs. 20 billion and a minimum of Rs. 8 billion. These measures led to a sharp decline in call money rates from an average of 9.14 per cent in December 
Table 2

Excess Liquidity and Interest Rates

\begin{tabular}{|l|r|r|r|r|c|c|}
\hline & \multicolumn{1}{|c|}{ Excess Liquidity* (Rs.bn) } & \multicolumn{3}{|c|}{ Average Interest Rates (\%) } \\
\cline { 2 - 7 } & \multicolumn{1}{|c|}{ Avg. } & \multicolumn{1}{|c|}{ Min. } & \multicolumn{1}{|c|}{ Max. } & OMO Auction & Call Money & Market Repo \\
\hline 2003 Mar & 9.54 & 6.44 & 13.71 & 9.17 & 9.46 & n.a. \\
Apr & 6.33 & 0.43 & 15.69 & 8.70 & 9.65 & n.a. \\
May & 9.71 & 2.80 & 14.01 & 8.70 & 9.01 & n.a. \\
Jun & 12.67 & 8.59 & 16.79 & 8.31 & 8.64 & n.a. \\
Jul & 11.28 & 8.37 & 14.69 & 8.29 & 8.59 & n.a. \\
Aug & 9.81 & 5.91 & 13.61 & 7.96 & 8.16 & 8.17 \\
Sep & 10.93 & 6.36 & 16.85 & 7.65 & 7.85 & 7.85 \\
Oct & 6.39 & 2.92 & 10.25 & 7.34 & 7.69 & 7.60 \\
Nov & 6.21 & 3.21 & 11.11 & 7.05 & 7.59 & 7.53 \\
Dec & 6.91 & 3.78 & 17.46 & 7.06 & 7.70 & 7.51 \\
Jan & 11.47 & 8.57 & 18.18 & 7.03 & 7.48 & 7.35 \\
Feb & 7.96 & 4.60 & 11.03 & 7.03 & 7.48 & 7.43 \\
Mar & 5.40 & 1.56 & 10.97 & 7.02 & 7.48 & 7.41 \\
Apr & 7.27 & 1.12 & 12.68 & 7.02 & 7.68 & 7.55 \\
May & 5.34 & 2.73 & 7.56 & 7.06 & 7.87 & 7.59 \\
Jun & 5.50 & 1.83 & 9.30 & 7.14 & 8.18 & 7.99 \\
Jul & 3.78 & 0.00 & 10.37 & 6.84 & 8.22 & 7.96 \\
Aug & 3.90 & 1.52 & 8.14 & 7.32 & 8.00 & 7.65 \\
Sep & 5.61 & 2.42 & 10.49 & 7.36 & 8.05 & 7.44 \\
Oct & 5.91 & 2.88 & 8.67 & 7.39 & 8.15 & 7.52 \\
Nov & 4.84 & 2.32 & 10.59 & 7.70 & 8.95 & 7.89 \\
Dec & 10.65 & 5.76 & 15.67 & 7.86 & 9.14 & 8.20 \\
Jan & 13.86 & 7.92 & 19.59 & 7.81 & 8.51 & 7.61 \\
Feb & 14.65 & 11.17 & 17.96 & 7.56 & 8.10 & 7.59 \\
Mar & 16.15 & 6.36 & 26.87 & 7.55 & 7.90 & 7.61 \\
Apr & 17.38 & 8.72 & 27.81 & 7.82 & 8.09 & 7.81 \\
May & 7.44 & -2.34 & 18.08 & 8.01 & 8.76 & 8.18 \\
Jun & 2.68 & -3.97 & 11.03 & 8.39 & 9.27 & 8.76 \\
\hline
\end{tabular}

* Actual excess liquidity as measured by total repurchase transactions with the Central Bank.

2004 to 8.25 per cent by end January 2005 and 8.06 per cent by 18 February 2005. The overnight repurchase rates in the market for transactions among commercial banks and primary dealers, which usually follow the daily OMO auction rate declined and remained closer to the lower bound of the interest corridor.

The daily auction was resumed on 21 February 2005 and in March, the Central Bank decided, in view of the concerns on excessive monetary 
expansion, to conduct its open market operations more aggressively which included absorbing the entire excess liquidity through the daily auction, while reducing excess liquidity through permanent absorptions. Accordingly, excess liquidity declined sharply, particularly in May and June 2005. The average yield rate at the daily OMO auction, which has remained closer to the lower bound of the interest rate corridor for more than a month since the resumption of the auction, moved up gradually from 7.54 per cent at end March 2005 to 7.89 per cent by end April 2005 and 7.95 per cent by 12 May 2005. Following the upward adjustment of the corridor by 25 bps on 12 May 2005, the average auction rate moved to 8.19 per cent by 19 May 2005. At the first auction held on 27 June 2005 following the policy rate adjustment (50 bps) on 15 June 2005 , the auction rate moved to 8.72 per cent, but declined to 8.58 per cent by end June due to a sharp increase in excess liquidity.

These movements in the auction rate were reflected in other short term interest rates as well. The average repurchase rate in the market reached nearly 8.0 per cent by 12 May 2005 and with the adjustment of the interest rate corridor, increased to 8.24 per cent on 13 May 2005. On several days, in May and June, the Central Bank did not conduct the daily auction, as the liquidity was broadly in balance. On these days, there were both repurchase and reverse repurchase transactions under the standing facility. However, the repurchase rates in the market remained remarkably stable around the middle of the corridor at 8.50 per cent up to 15 June 2005 and around 9 per cent thereafter. Inter bank call money rates followed a similar pattern and increased from an average of 7.90 per cent in March to 8.09 per cent in April. It increased from 8.20 per cent at end April 2005 to 8.50 per cent by 12 May 2005. With the increase in policy rates, it moved to 8.87 per cent on 13 May 2005 and with the decline in excess liquidity increased sharply to 9.25 by end May 2005 . There were volatile changes in call money rates in June 2005 with changes in excess liquidity.

\section{Standing Facility}

During March 2003 - mid May 2004, since only about 58 per cent of the excess liquidity was absorbed through the daily auction, the balance was absorbed under standing facility (Table 3). Standing facility also played an important role by providing an avenue for those who were unable to borrow in the market, despite there being excess liquidity, to obtain their fund requirements. It has been a generally observed fact, that certain banks with stringent limits on their lending to other banks have generated a large volume of excess liquidity mainly through their operations in the foreign exchange market and their business with corporate customers. As these banks invariably 
invest a large portion of their excess money with the Central Bank, when aggregate excess liquidity is relatively small, some banks were unable to borrow from the market and they had to resort to borrowing under standing facility from the Central Bank. Such occasions however, were very rare during March 2003 - May 2004 (only two occasions) as the market was well liquid.

Table 03

Standing Facility

Monthly Average

\begin{tabular}{|c|c|c|c|c|c|c|c|}
\hline & & $\begin{array}{c}\text { Repo } \\
\text { Rate }(\%) \\
(1)\end{array}$ & $\begin{array}{c}\text { R.Repo } \\
\text { Rate (\%) } \\
(2)\end{array}$ & $\begin{array}{c}\text { Repo } \\
\text { Volume } \\
\text { (Rs.bn) } \\
(3)\end{array}$ & $\begin{array}{c}\text { R.Repo } \\
\text { Volume } \\
\text { (Rs.bn) } \\
\text { (4) }\end{array}$ & $\begin{array}{c}\text { Excess } \\
\text { Liquidity } \\
\text { (Rs.bn) } \\
(5)\end{array}$ & $\begin{array}{c}\% \text { of absorbtion } \\
\text { through } \\
\text { Standing Facility } \\
3 \text { as } \% \text { of } 5\end{array}$ \\
\hline \multirow[t]{10}{*}{2003} & Mar & 9.00 & 11.00 & 4.17 & 0.01 & 9.54 & 44 \\
\hline & Apr & 9.00 & 11.00 & 3.04 & 0.19 & 6.33 & 48 \\
\hline & May & 9.00 & 11.00 & 3.04 & 0.19 & 6.33 & 48 \\
\hline & Jun & 8.25 & 10.25 & 6.08 & 0.00 & 12.67 & 48 \\
\hline & Jul & 8.25 & 10.25 & 3.96 & 0.00 & 11.28 & 35 \\
\hline & Aug & 7.84 & 9.84 & 3.23 & 0.00 & 9.81 & 33 \\
\hline & Sep & 7.50 & 9.50 & 3.04 & 0.00 & 10.93 & 28 \\
\hline & Oct & 7.24 & 8.98 & 2.56 & 0.00 & 6.39 & 40 \\
\hline & Nov & 7.00 & 8.50 & 2.76 & 0.00 & 6.21 & 45 \\
\hline & Dec & 7.00 & 8.50 & 3.95 & 0.00 & 6.91 & 57 \\
\hline \multirow[t]{12}{*}{2004} & Jan & 7.00 & 8.50 & 5.39 & 0.00 & 11.47 & 47 \\
\hline & $\mathrm{Feb}$ & 7.00 & 8.50 & 4.54 & 0.00 & 7.96 & 57 \\
\hline & Mar & 7.00 & 8.50 & 2.88 & 0.00 & 5.40 & 53 \\
\hline & Apr & 7.00 & 8.50 & 4.79 & 0.04 & 7.27 & 66 \\
\hline & May & 7.00 & 8.50 & 3.07 & 0.07 & 5.34 & 58 \\
\hline & Jun & 7.00 & 8.50 & 1.81 & 0.34 & 5.50 & 33 \\
\hline & Jul & 7.00 & 8.50 & 1.50 & 0.48 & 3.78 & 40 \\
\hline & Aug & 7.00 & 8.50 & 0.72 & 0.25 & 3.90 & 19 \\
\hline & Sep & 7.00 & 8.50 & 0.53 & 0.02 & 5.61 & 9 \\
\hline & Oct & 7.00 & 8.50 & 0.54 & 0.03 & 5.91 & 9 \\
\hline & Nov & 7.30 & 8.80 & 0.75 & 0.11 & 4.84 & 15 \\
\hline & Dec & 7.50 & 9.00 & 1.66 & 0.40 & 10.65 & 16 \\
\hline \multirow[t]{6}{*}{2005} & Jan & 7.50 & 9.00 & 13.11 & 0.00 & 13.86 & 95 \\
\hline & Feb & 7.50 & 9.00 & 12.66 & 0.06 & 14.65 & 86 \\
\hline & Mar & 7.50 & 9.00 & 2.35 & 0.00 & 16.15 & 15 \\
\hline & Apr & 7.50 & 9.00 & 1.40 & 0.01 & 17.38 & 8 \\
\hline & May & 7.64 & 9.14 & 1.53 & 0.69 & 7.44 & 21 \\
\hline & Jun & 8.01 & 9.51 & 1.94 & 1.29 & 2.68 & 72 \\
\hline
\end{tabular}

As the volume of excess liquidity was relatively small since June in 2004, some participating institutions resorted to borrowing under standing 
facility on several days in every month. Such borrowings were relatively heavy in June, July and August (Rs. 0.636 billion per day for 34 days). These were the months, in which a relatively large volatility in interest rates was observed. Towards end May in 2005, liquidity in the market became broadly in balance and due to limits of certain banks with excess liquidity, some borrowed under sanding facility (Rs. 2.636 billion per day for 5 days) while there were repurchase transactions also of similar magnitudes. Similar developments were observed in June 2005 as well.

\section{Outright Sales/Purchases of Government Securities}

During the first nine months of operations under the present system, though excess liquidity remained high in general while fluctuating within a wide range, outright sales of Treasury bills in the secondary market were not conducted to absorb a part of it on a permanent basis. However, to some extent, a permanent absorption has taken place at the maturity of the Treasury bills held by the Central Bank as maturity proceeds were not always reinvested. On the other hand, the Central Bank injected liquidity particularly during festive seasons, through purchases of Treasury bills at the primary auctions to ensure that excess liquidity remains broadly above Rs. 3 billion to maintain interest rate stability.

However, towards the end of 2003, excess liquidity exceeded well above Rs. 10 billion and hence, an attempt was made in January 2004, to absorb a part of it permanently through outright sales in the secondary market (Table 4). At first, attempts were made to sell through auctions, but given up after the second auction which was under subscribed and rejected as even the bids received were at rates higher than the comparable rates in the primary market. The first auction was over subscribed, but only Rs. 0.413 billion out of Rs. 1 billion offered was accepted as other bids were at rates higher than the comparable primary market rates. The Central Bank however, managed to sell Treasury bills to a face value of Rs. 1.9 billion in the secondary market in January 2004 through direct dealings. These sales were at rates comparable with the primary auction rates. One advantage of direct dealings was that a counter party could negotiate and purchase bills of his desired tenure (number of dates to maturity), whereas at the auction, bills of only one maturity could be offered at a time.

Outright sales were not conducted during the rest of the year 2004, as there was a tendency for market liquidity to decline particularly due to the transactions of the Central Bank in the foreign exchange market. Instead, the Central Bank purchased Treasury bills outright in the secondary market on three occasions in 2004 to prevent the market becoming short in liquidity. 
Table 04

Outright Sales (Auctions) of Treasury Bills in the Secondry Market

\begin{tabular}{|c|c|c|c|c|c|c|c|c|}
\hline \multirow{2}{*}{\multicolumn{2}{|c|}{$\begin{array}{c}\text { Auction } \\
\text { Date }\end{array}$}} & \multirow{2}{*}{$\begin{array}{l}\text { Amount } \\
\text { Offered } \\
\text { (Rs.bn) }\end{array}$} & \multirow{2}{*}{$\begin{array}{l}\text { No. of } \\
\text { Days to } \\
\text { Maturity }\end{array}$} & \multirow{2}{*}{$\begin{array}{c}\text { Bid } \\
\text { Received } \\
\text { (Rs.bn) }\end{array}$} & \multirow{2}{*}{$\begin{array}{c}\text { Bid } \\
\text { Accepted } \\
\text { (Rs.bn) }\end{array}$} & \multicolumn{3}{|c|}{ Yield (\%) } \\
\hline & & & & & & Weighted & Min. & Max. \\
\hline 2004 & $\begin{array}{r}\text { 8-Jan } \\
14-J a n\end{array}$ & $\begin{array}{l}1.00 \\
0.75\end{array}$ & $\begin{array}{l}84 \\
98\end{array}$ & $\begin{array}{l}1.91 \\
0.55\end{array}$ & $\begin{array}{l}0.41 \\
0.00\end{array}$ & 7.39 & 7.37 & 7.40 \\
\hline Total & & 1.75 & & 2.46 & 0.41 & & & \\
\hline 2005 & 1-Apr & 1.00 & 32 & 2.95 & 1.00 & 7.64 & 7.63 & 7.65 \\
\hline & 4-Apr & 2.00 & 45 & 4.53 & 2.00 & 7.67 & 7.65 & 7.72 \\
\hline & 5-Apr & 2.00 & 51 & 1.49 & 1.43 & 7.90 & 7.80 & 8.00 \\
\hline & 20-Apr & 2.00 & 36 & 5.83 & 0.00 & & & \\
\hline & 26-Apr & 3.00 & 37 & 7.29 & 3.00 & 8.06 & 8.00 & 8.15 \\
\hline & 28-Apr & 3.00 & 42 & 7.64 & 3.00 & 8.12 & 8.08 & 8.15 \\
\hline & 29-Apr & 3.00 & 45 & 6.11 & 3.00 & 8.13 & 8.08 & 8.15 \\
\hline & 3-May & 3.00 & 58 & 1.95 & 0.83 & 8.22 & 8.19 & 8.25 \\
\hline & 6-May & 2.00 & 18 & 7.39 & 2.00 & 7.95 & 7.95 & 7.95 \\
\hline & 10-May & 2.50 & 44 & 5.72 & 2.50 & 8.19 & 8.10 & 8.23 \\
\hline & 30-Jun & 3.00 & 14 & 7.74 & 3.00 & 8.84 & 8.75 & 8.99 \\
\hline & 7-Jul & 2.00 & 7 & 3.30 & 2.00 & 9.00 & 8.98 & 8.99 \\
\hline Total & & 28.50 & & 61.93 & 23.76 & & & \\
\hline
\end{tabular}

Note: settlement on the business day fillowing the Auction date.

It was practically not possible to purchase a large volume of securities from the market without their yield rates being affected. Moreover, Treasury bills were not available in sufficient volumes in trading portfolios of dealers and the Central Bank was not dealing in Treasury bonds on an outright basis.

During the first four months in 2005, excess liquidity remained well above Rs. 15 billion on most of the days and this excess liquidity was considered as one of the factors which contributed towards the high monetary expansion. Accordingly, outright sales of Treasury bills out of the Central Bank holding were commenced on 1 April 2005 and by 10 May 2005, 10 auctions were conducted and excess liquidity of Rs. 18.8 billion was absorbed on a permanent basis. Among the auctions, seven were well subscribed and highly successful. One auction was rejected as bids were at unacceptably high yield rates. Two auctions were at relatively high rates and only partially accepted.

Following limitations were observed in the absorption of excess liquidity on a permanent basis. 
i. Due to limitations of the portfolio of Treasury bills held by the Central Bank, it may not always be possible to offer for outright sales, securities of which tenure is well demanded by participating institutions. Most often Central Bank had to offer for sales, odd maturities which were not in demand in general. The experience was that, market preferred short maturities of around one to one and half months. The available volume of such maturities may get depleted quickly when the required volume of permanent absorption is relatively large.

ii. The existing electronic system for conducting auctions also has a limitation of not being able to offer for an auction securities of more than one maturity, i.e., inability to conduct multiple auctions simultaneously. If such a facility were available, a large volume could have been offered while providing an opportunity for participating institutions to select preferred maturities. This difficulty however, was overcome through direct dealings. Direct dealings are not much encouraged in view of transparency considerations, particularly as facilities for on the screen firm quotes and dealings are not available.

\section{Reserve Money Targets and Interest Rate Volatility}

As noted in Section 2, the Central Bank was successful in 2003, in achieving its targets on reserve money while maintaining short term interest rates stable at a level closer to the lower bound of the interest rate corridor. In 2004, reserve money tended to remain above the desired paths and shot term interest rates displayed some volatility. This section outlines the approach adopted by the Central Bank to bring the reserve money to the target path and examine the factors which contributed to the volatility observed in short term interest rates.

\section{A. Reserve Money Targets}

The difficult economic conditions which were brought about by weather related domestic supply disturbances and the escalation of international oil prices that prevailed in 2004 required proper timing and sequencing of monetary policy tightening. ${ }^{2}$ Accordingly, as the first step, the Central Bank conducted its OMO aggressively from May by absorbing almost the entire excess liquidity through the daily actions and thereby, induced an upward

2/ Central Bank of Sri Lanka (2004), Annual Report, p116. 
adjustment in short-term interest rates. Subsequently in November 2004, the policy rates were increased by 25 bps.

Following the Tsunami disaster on 26 December, 2004, in view of the need for ensuring smooth operations of the payment and settlement system and supporting the needs for relief and rehabilitation of areas affected by Tsunami, the absorption of excess liquidity through the daily OMO auction was, first substantially reduced and then temporarily suspended during 5 January - 18 February, 2005 while maintaining a relatively high volume of excess liquidity in the market. This resulted in a sharp reduction in interest rates. The average call money rates declined from 9.63 per cent on 24 December 2004 , to 8.06 per cent by 18 February 2005 while the average market repurchase rate declined from 7.96 per cent to 7.57 per cent during the same period. By end March 2005, reserve money exceeded the target which however, was largly attributed to higher than usual increase in currency in circulation owing to the additional demand created by Tsunami relief and rehabilitation operations.

Excess liquidity which remained around Rs. 15 billion on average, during the first three months of 2005 was one of the main factors which contributed to the higher monetary expansion. Therefore, as an instrument for bringing the reserve money back to its desired path, it was decided in April 2005 to conduct OMO aggressively. This included the absorption of a large part of excess liquidity on a permanent basis, through outright sales of Treasury bills out of the Central Bank holdings and absorbing the balance entirely through the daily OMO auction.

Accordingly, outright sales were commenced on 1 April 2005 and by 11 May 2005, excess liquidity of Rs. 18.8 billion was absorbed on a permanent basis (Table 4) and excess liquidity which was as high as Rs. 28 billion on 26 April, 2005 was brought to below Rs. 10 billion. Treasury Bill holdings of the Central Bank declined from Rs. 85.0 billion (net of repurchase, Rs.62.4 billion) at end March 2005 to Rs.61.9 billion (net of repurchase, Rs.52.4 billion) by 11 May 2005 (Table 5). The yield rate at daily OMO auction moved up to 7.94 per cent from 7.56 per cent at end March 2005. By end May 2005, market liquidity was brought to a balance position and the average repurchase rate in the overnight market moved to 8.49 per cent from 7.59 per cent at end March 2005. These positive developments were consolidated by 25 bps and 50 bps increases in the repurchase rate and the reserve repurchase rate of the Central Bank on 13 May and 15 June 2005, respectively.

The conduct of OMO aggressively, together with subsequent adjustments in policy rates has been instrumental in bringing the reserve money to its target level in June 2005. 


\section{B. Interest Rate Volatility}

It was expected that the present system of monetary operations would enable the Central Bank to maintain overnight interest rates stable around a level considered consistent with the reserve money target. In 2003, interest rates were quite stable around a level closer to the bottom of the corridor. In fact, as measured by the standard deviation in average call money rates, there had been a significant improvement in interest rate stability in 2003 when compared with the second half of 2002 (Chart 4). However, rates had displayed a high degree of volatility in May 2004. In most of 2004 and early 2005, interest rates moved within a wider range, with changes in excess liquidity (Chart 5).

One of the main reasons for volatile changes in interest rates was the self imposed limits of banks on their lendings to other banks. Such limits of some banks particularly, of foreign banks were quite stringent. When such a bank has built up a large surplus, some may find it extremely difficult to borrow in the inter bank market unless there is a large volume of excess liquidity. Under such a situation, it was not uncommon to observe both repurchase and reverse repurchase transactions with the Central Bank on a same day. This may result in volatile changes in interest rates and the degree of volatility would be higher, the smaller the size of excess liquidity. Normally, excess

Table 05

Tresury Bills holdings of Central Bank

\begin{tabular}{|c|c|c|c|c|c|c|c|}
\hline & & $\begin{array}{c}\text { Gross } \\
\text { Book Value }\end{array}$ & $\begin{array}{l}\text { Net of Repo } \\
\text { Book Value }\end{array}$ & & & $\begin{array}{c}\text { Gross } \\
\text { Book Value }\end{array}$ & $\begin{array}{l}\text { Net of Repo } \\
\text { Book Value }\end{array}$ \\
\hline \multirow[t]{10}{*}{2003} & Mar & 38.19 & 30.44 & \multirow[t]{14}{*}{2004} & May & 41.40 & 35.30 \\
\hline & Apr & 38.90 & 22.16 & & Jun & 46.20 & 37.60 \\
\hline & May & 39.77 & 26.10 & & Jul & 53.00 & 45.70 \\
\hline & Jun & 32.31 & 20.87 & & Aug & 56.00 & 47.90 \\
\hline & Jul & 27.12 & 10.53 & & Sep & 61.00 & 50.50 \\
\hline & Aug & 22.16 & 10.17 & & Oct & 72.70 & 64.50 \\
\hline & Sep & 13.97 & 2.23 & & Nov & 84.50 & 73.90 \\
\hline & Oct & 11.01 & 3.52 & & Dec & 82.00 & 74.80 \\
\hline & Nov & 19.07 & 10.83 & & Jan & 81.94 & 66.41 \\
\hline & Dec & 29.08 & 11.62 & & Feb & 82.70 & 66.50 \\
\hline \multirow[t]{4}{*}{2004} & Jan & 26.50 & 14.00 & & Mar & 85.00 & 62.40 \\
\hline & $\mathrm{Feb}$ & 26.90 & 17.00 & & Apr & 73.40 & 53.90 \\
\hline & Mar & 43.30 & 32.30 & & May & 57.40 & 52.70 \\
\hline & Apr & 42.50 & 32.10 & & Jun & 62.65 & 51.62 \\
\hline
\end{tabular}


liquidity of around Rs. 3 - 5 billion was required to maintain interest rates stable at their existing level.

Accordingly, as a practice, in 2003 and the first half of 2004, the Central Bank kept the market well liquid, through its purchases of Treasury bills. Particularly during festive seasons, the Central Bank planned in advance its purchases of Treasury bills to ensure that the market is sufficiently liquid. Though this practice had been successful in maintaining interest rates fairly stable, there were instances when rates increased sharply as the liquidity injected was not sufficient due to demand being exceptionally higher than the projection. Since the width of the corridor was $150 \mathrm{bps}$ and the OMO auction rate was closer to the lower bound of the corridor, there was a scope for large fluctuations in rates.

There was also a period in which interest rates displayed a tendency to move up even when there was a sufficiently large volume of excess liquidity in the market. During October - December 2004, call money rates showed an upward trend with a sharper increase in November and December 2004. The increase in November was partly a reflection of the increase in Central Bank policy rates by 50 bps on 12 November 2004. However, even before the policy rate adjustment, the upward trend was observed. For example, the weighted average call money rate increased from 8.25 per cent at end October 2004 to 8.86 per cent on 10 November 2004 , despite the market being quite liquid with excess liquidity of around Rs. $4-6$ billion. Just prior to the policy rate adjustment, the average call money rate exceeded the upper bound of the interest rate corridor and continued to remain above the upper bound with an

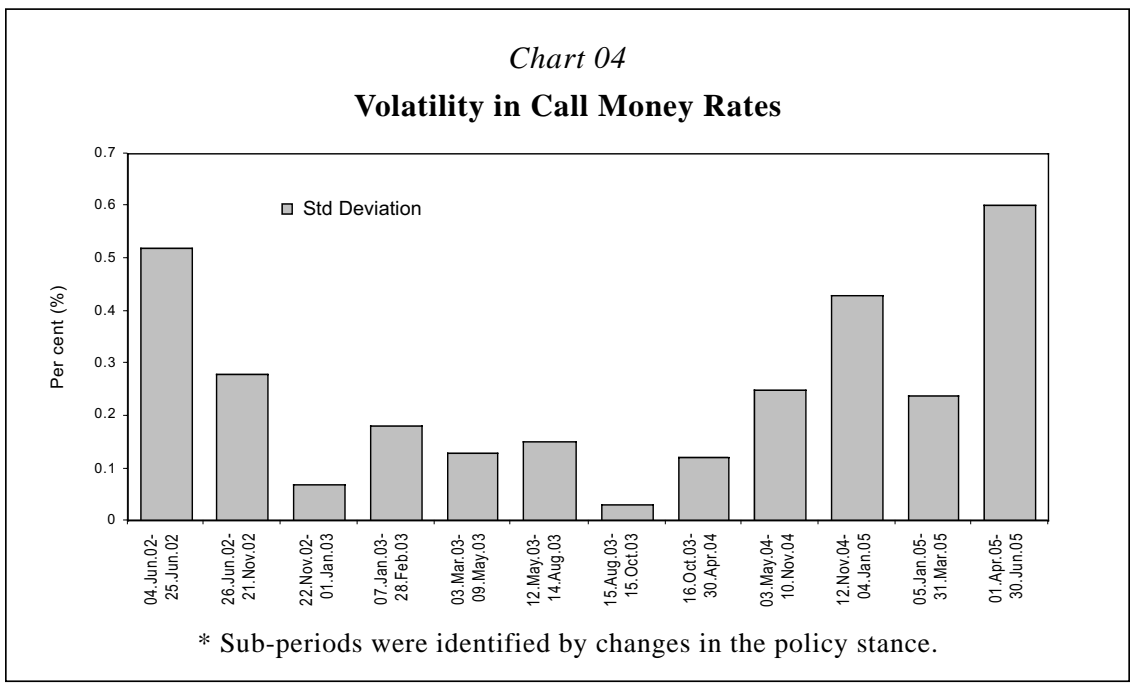




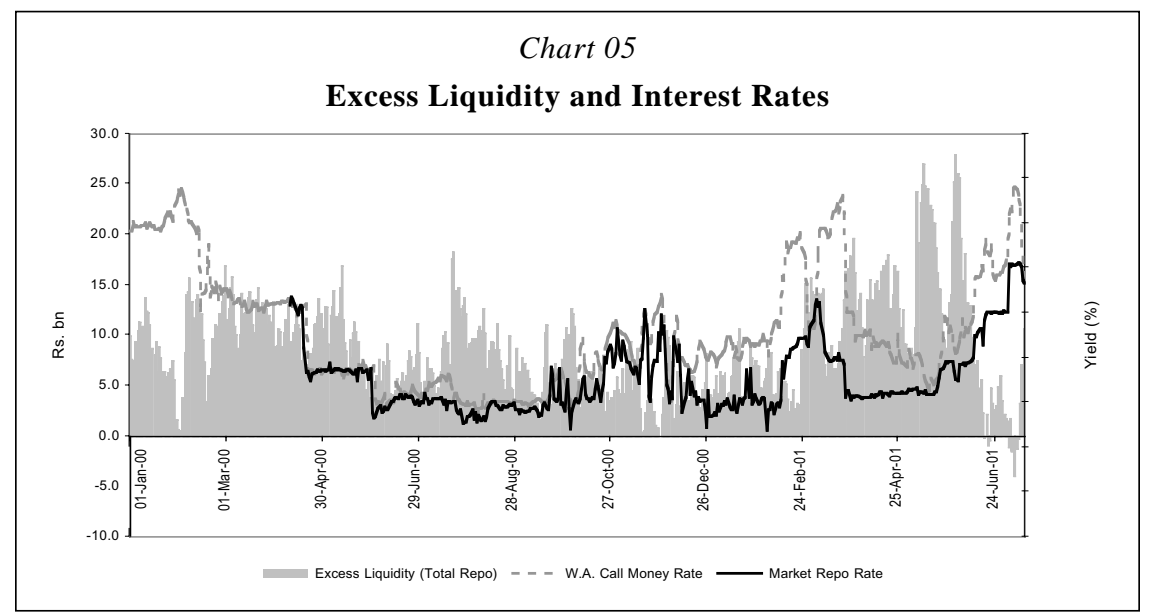

upward trend, except for a brief period between end November and 10 December 2004, when the average rate remained relatively low due to a temporary concentration of liquidity in a single bank. ${ }^{3}$ During the second half of December 2004, even a sharper movement in rates was observed though the market operated with a liquidity surplus of well above Rs. 6 billion.

The sharp increase in call money rates was partly due to an unusual development in government debt securities market which augmented the implications on the market, of the constraint imposed by limits on inter-bank lending. There was an anomaly in yield rates of government securities as yield rates on 91 day Treasury bills and 182 day Treasury bills (during most of the period) were below the Central Bank repurchase rate. The anomaly was larger when compared with the OMO auction rate. Therefore, there was an advantage in investing on a repurchase basis rather than purchasing those Treasury bills on an outright basis. Moreover, given the fact that inflation was rising and monetary expansion was above the target investors would have presumed that rates were not sustainable.

Therefore, there was a reluctance among some investors to hold government securities, except on a very short term basis. In particular, some foreign banks liquidated a part of their holdings of government securities and invested the proceeds in the repurchase market. They could not invest proceeds in the call market as they have to maintain a stock of government securities in their portfolio of assets in the balance sheets. This led to a concentration of a significant volume of excess liquidity in foreign banks. There was a

3/ For details, see page 31 
concentration of liquidity among primary dealers as well. Usually primary dealers borrow funds under repurchase agreements and maintain a stock of securities for trading purposes. However, under these prevailing conditions, some primary dealers, met their customers' demand by selling Treasury bills on a repurchase basis which were backed by, their investment under repurchase transactions with the Central Bank. As some borrowers in overnight money markets did not have securities to borrow in the repurchase market, they had to depend entirely on the call money market in which a significant portion of excess liquidity was not available. The market forces however induced necessary adjustments in rates and the anomaly disappeared within a short period.

There were also instances where some banks lent in the call market at rates which were below the Central Bank repurchase rate. It happened, particularly, in the case of foreign banks when their portfolio limits on government securities were reached. Under such instances, they had no choice but to lend in the call market even at relatively low rates. The situation became worse when their lending limits to major borrowers were rather stringent. There could also be volatile changes in rates due to a concentration of a large volume of liquidity temporarily in a single bank due to an exceptional reason. A case in point was the concentration of a large volume of liquidity in a single bank following a heavy over subscription of Lanka IOC share issue in November 2004. Initially, rates declined sharply as borrowers expected this bank to lend at relatively low rates. Subsequently however, rates improved on the realization that there was a demand for a large volume of funds.

Accordingly, there could be volatile changes in call money rates due to a number of reasons, which included self-imposed limits of banks on their lending to other banks, behaviour of rates in government debt securities market, portfolio limits of banks on holding of various types of assets in their balance sheets, holdings of securities traded in repurchase market $e t c$. The volatility created by these factors could not necessarily be addressed by monetary policy operations though attempts have been made in the past, to keep the market sufficiently liquid to overcome the constraints imposed by such factors.

An unsatisfactory feature observed, particularly during most of 2004 and early 2005 was the fluctuation of interest rates, with changes in excess liquidity. Interest rates would have not fluctuated with changes in excess liquidity if lenders were indifferent between lending in the inter-bank market and lending to the Central Bank. However, quite often, there was a divergence between comparable market rates and the OMO auction rate. The divergence existed mainly because the prevailing conditions in the country did not permit countinouse absobtion of the entire excess liquidity through the OMO auction. If the market were operating around the middle of the corridor, and the entire 
volume of excess liquidity were absorbed through OMO auction at market rates, market rates would have not fluctuated simply due to changes in excess liquidity.

\section{Suggestions for Improving Effectiveness of Monetary Policy Operations}

The Central Bank has successfully implemented the present system of monetary policy operations, though during a certain period, the achievement of the expected outcome of the system was constrained by reasons beyond the control of the Central Bank. Nevertheless, as identified through the experiences since March 2003, there is a scope for further improving the system.

\section{A. Operating Target}

It seems that there is a need for refocusing on monetary targets and instruments and identifying precisely the role of each instrument. In particular, it seems more appropriate that the operating target is redefined.

It has been a usual practice to consider reserve money which is derived from the balance sheet of the Central Bank and hence presumed as being under the control of the Central Bank as the operating target of monetary policy. However, this presumption is not quite correct, particularly under the present system of monetary policy operations. Reserve money is comprised of balances held by commercial banks with the Central Bank which are governed by Statutory Reserve Requirements (SRR) and hence are fixed, and currency outstanding which are exogenous in the short run. On the other hand, reserve money is released by the accumulation of net foreign assets (NFA) and net domestic assets (NDA) by the Central Bank. Whenever there is an increase in NFA, there would be a corresponding decline in NDA through an increase in sales of Treasury bills on repurchase basis or a decline in purchases of securities on reverse repurchase basis to absorb the liquidity created by the increase in NFA. Even if the Central Bank did not make a discretionary step to absorb the liquidity, the absorption would take place through standing facility. Similarly, the impact of a reduction in NFA would be neutralized through an increase in NDA. More specifically, if the Central Bank sells Treasury bills outright to reduce reserve money, it would not be materialized directly as there would be a corresponding decline in repo sales or an increase in reserve repo purchases, leaving the stock of government securities held by the Central Bank unchanged.

Accordingly, since the Central Bank does not have a direct control over the reserve money, it is not quite appropriate to use it as an operational target. 
In fact, it is an intermediate target which is to be achieved by changing interest rates. An operating target of reserve money may lead to excessive volatility in interest rates, which would make it more difficult for the Central Bank to signal its monetary policy stance. The monetary policy operations of the Central Bank affects reserve money, only through their impact on short term interest rates. Therefore, it is more appropriate to consider reserve money as an intermediate target, and short term interest rates as the operating target. The only market based instrument available to achieve the reserve money target is the interest rate corridor and normally it implies an implicit target on interest rates usually in the middle of the corridor. This implicit target is considered as being consistent with the reserve money target.

This approach is consistent with the 'Monetary Target and Instrument Framework' suggested in Peter Dattels' report. ${ }^{4}$ However there is a concern in moving to this approach as interest rates may become volatile due to factors as outlined in section 4.2, which are beyond the control of the monetary authority. These factors are rigidities which will eventually be relieved through improved competition and strengthening of financial institutions.

\section{B. Daily Repurchase Auctions}

The instrument to achieve the interest rate target is the daily repurchase auction. The size of the auction needs to be set to achieve the desired interest rate outcome. Normally, monetary operating target would be on overnight call money rates. However, in view of the divergence between call money rates and repurchase rates created by a tax credit of 1/9th of interest earned on secondary market operations in government securities in Sri Lanka, the monetary operating target needs to be set on the overnight repurchase rate for transactions among commercial banks and primary dealers, as it is the rate comparable with the policy rates of the Central Bank which are for transactions on a repurchase basis. Accordingly, the daily auction should be conducted to maintain the market repurchase rate around the implicit target which is usually in the middle of the corridor.

Therefore, the size of the auction need to be determined only by considering its outcome on interest rates to achieve the interest rate target (implicit). This is more consistent with the approach adopted by advanced countries and inflation targeting countries and hence, would facilitate eventual move to inflation targeting monetary policy framework.

4/ 'A Strategy for Strengthening the Framework and Implementation of Monetary and Foreign Exchange Operations.' IMF Technical Assistance report prepared by Peter Dattels etc. (August 2001). 


\section{Management of Short Term Liquidity and Interest Rate Stability}

As long as the size of the daily auction is set to maintain short term interest rates at the implicit target, preferably in the middle of the corridor, changes in the volume of excess liquidity would not necessarily lead to significant fluctuations in interest rates. Specifically, at the target rate, if there is a liquidity surplus, it should be absorbed through the auction and if there is a deficit, liquidity should be injected to cover the entire deficit. As long as the auction rate converges with the market rate, the target rate could be maintained and there would not be a significant change in interest rates, even if liquidity in the market shifts from a surplus to a deficit. However, in setting the auction size, due attention needs to be paid on constrains arising from rigidities such as limits on inter-bank lending.

As long as the OMO auction rate converges with market rate, there would not be a pressing need to provide liquidity through purchases of Treasury bills to meet seasonal demand in months of March/April and December, as the required liquidity could be injected through daily auction of reverse repurchase transactions. As long as the entire increase in the demand for liquidity is accommodated at the prevailing market rate, it should not lead to fluctuations in interest rates.

\section{Management of Long Term Liquidity}

Though, interest rates should not fluctuate with changes in the volume of liquidity in principle as long as the daily OMO auction is conducted to maintain the implicit interest rate target, there is a normal tendency for interest rates to decline (increase) when market operates with an excessively large liquidity surplus (deficit). Therefore, it is essential that liquidity surplus or deficit in the market is not allowed to be excessive through outright transactions in government securities. In this regard, it is important that the constraints for outright transactions noted in Section 3 are removed particularly through following actions for which, initiatives have already been taken.

a. introduce long term repurchase transactions as an additional instrument for managing long term liquidity. This would help alleviating the constrain imposed by the lack of securities of tenure, demanded by investors.

b. enhance the facilities available in the electronic system for conducting auctions, to enable the conduct of multiple auctions simultaneously. 


\section{References}

Central Bank of Sri Lanka (2004), Annual Report, Central Bank of Sri Lanka, Colombo.

Central Bank of Sri Lanka (2003), "Initial Experience and Challenges Under Active Open Market Operations", Annual Report, Box Article No. 4, Central Bank of Sri Lanka, Colombo.

Central Bank of Sri Lanka (2001), "More Active Open Market Operations", Box Article No. 20, Annual Report, Central Bank of Sri Lanka, Colombo.

Dattels, Peter and others (2001), "Sri Lanka: A Strategy for Strengthening the Framework and Implementation of Monetary and Foreign Exchange Operations" Technical Assistance Report, International Monetary Fund, Washington D.C. 